\title{
PENGARUH PERSEPSI TENTANG SERTIFIKASI GURU, STRATEGI PENYELESAIAN KONFLIK, DAN MOTIVASI KERJA TERHADAP PRODUKTIVITAS KERJA GURU SMKN
}

\author{
Tri Atmadji Sutikno \\ FT Universitas Muhammadiyah Malang \\ email: atmadji_tri@yahoo.com
}

\begin{abstract}
Abstrak: Penelitian ini bertujuan untuk mengetahui pengaruh persepsi tentang sertifikasi guru, strategi penyelesaian konflik, motivasi kerja, terhadap produktivitas kerja. Populasi penelitian adalah guru-guru SMKN Malang Raya sedangkan sampel (278 guru) diambil secara acak. Data dianalisis dengan analisis deskriptif dan korelasional. Hasil penelitian menunjukkan bahwa: (1) persepsi tentang sertifikasi guru, strategi penyelesaian konflik, motivasi kerja dalam kategori tinggi, dan produktivitas kerja guru dalam kategori sedang; (2) ada hubungan antara (a) persepsi tentang sertifikasi guru, strategi penyelesaian konflik dengan motivasi kerja, (b) strategi penyelesaian konflik, motivasi kerja dengan produktivitas, (3) tidak ada hubungan antara persepsi tentang sertifikasi guru dengan produktivitas kerja.
\end{abstract}

Kata Kunci: sertifikasi guru, strategi penyelesaian konflik, motivasi kerja, produktivitas kerja

\section{THE INFLUENCE OF PERCEPTION ON TEACHER CERTIFICATION, CONFLICT RESOLUTION STRATEGIES, AND WORK MOTIVATION ON WORK PRODUCTIVITY OF SMKN TEACHERS IN MALANG}

\begin{abstract}
This study was aimed to investigate the influence of perception on teacher certification, conflict resolution strategies, and work motivation on work productivity. The population was SMK teachers in Malang and the sample (278 teachers) was taken randomly. The data were analyzed using descriptive and correlational analyses. The findings showed: (1) perception about teacher certification, conflict resolution strategies, work motivation belonged to the high category while the work productivity belonged to the fair category, (2) there are relationships between (a) perception about teacher certification, conflict resolution strategies and work motivation, (b) conflict resolution strategies, work motivation and work productivity, (3) there is no relationship between perception about teacher certification and work productivity.
\end{abstract}

Keywords: teachercertification, conflict resolution strategies, work motivation, and work productivity

\section{PENDAHULUAN}

Sekolah Menengah Kejuruan (SMK) sebagai bentuk satuan pendidikan kejuruan sebagaimana ditegaskan dalam penjelasan pasal 15 UU SISDIKNAS, merupakan pendidikan menengah yang mempersiapkan peserta didik terutama untuk bekerja dalam bidang tertentu. Pendidikan kejuruan bertujuan untuk mem-bekali siswa agar memiliki kompetensi perilaku dalam bidang kejuruan tertentu sehingga yang bersangkutan mampu bekerja (memiliki kinerja) demi masa depannya dan bangsanya (Schippers\& Patriana, 1993:18). Dalam pendidikan kejuruan siswa dibekali pengetahuan teori dan keterampilan praktis, serta pola dan tingkah laku sosial dan wawasan berkebangsaan.

Pendidikan kejuruan, khususnya Sekolah Menengah Kejuruan, merupakan investasi untuk meningkatkan kualitas sumber daya manusia, yang merupakan syarat utama untuk meningkatkan laju pertumbuhan ekonomi, pemerataan kesempatan dan perubahan sosial (yang bersangkutan mampu bekerja (memiliki kinerja) demi masa depannya dan bangsanya (Schippers \& Patriana, 1993:22). Kebijakan adanya pendidikan kejuruan mencakup: (1) kebijakan perekonomian, (2) kebijakan ketenagakerjaan, dan (3) kebijakan kebudayaan. 
Agar tujuan Sekolah Menengah Kejuruan tercapai diperlukan pendidik dan tenaga kependidikan yang berkualitas, sarana prasarana yang memadai, proses, dan metode pembelajaran yang mendukung, serta pengelolaan yang baik. Pendidik, yang dalam hal ini guru, menduduki posisi strategis untuk mewujudkan tujuan pendidikan nasional, karena guru sebagai tenaga pendidik yang terlibat langsung dalam aktivitas proses pembelajaran di kelas dan seluruh proses pendidikan di sekolah. Pendidik dituntut memiliki sejumlah persyaratan (kualifikasi, kompetensi, sertifikat pendidik) agar dapat berperan sebagai guru yang profesional. Jika sejumlah persyaratan tersebut terpenuhi, perannya akan dapat menentukan maju mundurnya produktivitas organisasi.

Produktivitas kerja guru merupakan keluaran dari tugas-tugas guru yang tertuang dalam tugas pokok dan fungsi guru (Depdiknas, 2009; Suparlan, 2005:89). Tugas pokok dan fungsi guru adalah membantu dan bertanggungjawab kepada kepala sekolah dalam kegiatan belajar mengajar, diantaranya: (1) membuat kelengkapan mengajar dengan baik dan lengkap, (2) melaksanakan kegiatan pembelajaran, (3) melaksanakan kegiatan penilaian proses belajar, ulangan harian, ulangan umum dan ujian akhir, (3) melaksanakan analisis hasil ulangan harian, (4) menyusun dan melaksanakan program perbaikan dan pengayaan, (5) mengisi daftar nilai anak didik; (6) melaksanakan kegiatan membimbing (pengimbasan pengetahuan), kepada guru lain dalam proses pembelajaran; (7) membuat alat pelajaran/alat peraga; (8) menumbuh- kembangkan sikap menghargai karya seni; (9) mengikuti kegiatan pengembangan dan pemasyarakatan kurikulum; (10) melaksanakan tugas tertentu di sekolah; (11) mengadakan pengembangan program pembelajaran; (12) membuat catatan tentang kemajuan hasil belajar anak didik; (13) mengisi dan meneliti daftar hadir sebelum memulai pelajaran; (14) mengatur kebersihan ruang kelas dan sekitarnya; dan (15) mengumpulkan dan menghitung angka kredit untuk kenaikan pangkat.

Produktivitas kerja dipengaruhi oleh motivasi kerja, seperti pendapat Ranftl (1989: 111) yang mengatakan bahwa motivasi disebut sebagai faktor kritis dan pegawai yang termotivasi berada di jalan produktivitas yang tinggi. Daft (2003) menjelaskan bahwa motivasi seseorang mempengaruhi produktivitas, dan sebagian tugas seorang manajer adalah menyalurkan motivasi menuju pencapaian tujuan-tujuan organisasional. Hal senada disampaikan oleh Brookfiled (1989:124) bahwa manajemen yang tidak berorientasi pada manusia dan tidak cukup perhatian pada motivasi pegawai akan menyebabkan penurunan produktivitas .

Untuk mencapai tujuan organisasi sekolah, tidak jarang terjadi perbedaan persepsi atau pandangan diantara individu atau diantara kelompok individu dalam menterjemahkan misi organisasi sehingga menimbulkan konflik, dan tentu dengan adanya konflik dapat menurunkan motivasi kerja jika tidak ada pengelolaan yang baik. Konflik membuat iklim organisasi tidak kondusif dan menyebabkan tidak tercapainya tujuan organisasi secara optimal. Agar konflik dapat mempunyai dampak positif bagi organisasi, konflik perlu dikekola dengan baik. Hersey \& Blanchard (1986) menyatakan, kemampuan pemimpin organisasi dalam penanggulangan konflik dapat berpengaruh pada produktivitas kerja organisasi.

Sebagai upaya menetapkan standar dan meningkatkan kualitas guru, Departemen Pendidikan Nasional (Depdiknas, 2009) menyelenggarakan program Sertifikasi Guru dalam Jabatan. Sertifikasi guru yang telah dilaksanakan sejak tahun 2007 tersebut tentu mendapatkan persepsi yang beragam dari para guru dan pemerhati pendidikan. Baedhowi dalam sidang Senat pengukuhan guru besar di UNS mengatakan meskipun guru telah mengikuti sertifikasi, namun tidak serta merta kompetensi mereka meningkat, bahkan menunjukkan penurunan kinerja. Menurut Baedhowi, persepsi yang ditangkap guru tentang sertifikasi hanya sebatas peningkatan kesejahteraan. Padahal seharusnya tidak hanya tentang peningkatan kesejahteraan namun harus dibarengi dengan peningkatan kompetensi (Untari, 2008).

It is intellectually unjustifiable at this time to establish a particular set of behavior 
indicators of teacher competence as certification criteria.Hasil-hasil penelitian banyak menunjukkan adanya pengaruh antara pengendalian konflik, dengan motivasi kerja guru. Penelitian Salabi (2006: 220) yang dilakukan pada Madrasah Aliyah Negeri di Propinsi Kalimantan Selatan menemukan bahwa pengendalian konflik berhubungan dengan produktivitas kerja organisasi. Sedang, penelitian Supriyanto (2005: 186) di SMAN bandung menyimpulkan bahwa faktor motivasi individu memiliki pengaruh yang sangat nyata terhadap kinerja guru.

Produktivitas kerja guru pada Sekolah Menengah Kejuruan di Malang Raya menjadi pertanyaan akhir-akhir ini, itu dibuktikan dengan hasil kelulusan siswa pada ujian nasional tiga tahun terakhir yang mengalami penurunan secara signifikan. Untuk Jawa Timur angka ketidaklulusan siswa pada tahun 2008 sebesar 3,12\%, tahun 2009 meningkat menjadi 5,48\%, dan tahun 2010 angka ketidaklulusan meningkat menjadi 7,078\% (Diknas Jawa Timur). Persentase ketidaklulusan siswa SMK di Malang Raya seperti Tabel 1.

Tabel 1. Persentase Ketidaklulusan SMK di Malang Raya

\begin{tabular}{llcl}
\hline Kota & 2008 & 2009 & $2010(\%)$ \\
\hline Kota Malang & $14,05 \%$ & $13,11 \%$ & $17,83 \%$ \\
Kab. Malang & $7,94 \%$ & $8,60 \%$ & $9,89 \%$ \\
Kota Batu & $24,19 \%$ & $21,20 \%$ & $29,88 \%$ \\
\hline
\end{tabular}

Sumber: Diknas Kota Malang, Kota Batu, dan Kabupaten Malang

Dengan memperhatikan Tabel 1 tersebut persentase ketidaklulusan siswa pada tahun 2010 lebih tinggi dari tahun-tahun sebelumnya, hal ini diduga jumlah SMKN di Kabupaten Malang yang lebih kecil (enam sekolah) sehingga pengelolaannya lebih terkoordinasi dibanding SMKN di Kota Malang (dua belas sekolah). Tetapi secara umum ketidaklulusan siswa dalam Unas yang semakin meningkat pada tiga tahun terakhir tersebut menunjukkan adanya kinerja guru yang rendah, dan berdampak pada penurunan produktivitas kerja guru. Berdasar Tabel 1 ketidaklulusan.

Sertifikasi guru menjadi permasalahan dalam pelaksanaannya. Ini dibuktikan dari pe- nelitian Sudarman (2008) tentang tanggapan guru-guru terhadap kebijakan sertifikasi guru, yang melalui penilaian portofolio dan PLPG, menemukan bahwa masih banyaknya guru-guru yang bermoral kurang baik dengan melakukan segala macam cara untuk melengkapi dokumendokumen portofolio yang dipersyaratkan. Konflik banyak terjadi di sekolah, seperti yang diungkapkan Suparlan (2009) dalam sebuah seminar bahwa banyak terjadi konflik internal dalam menentukan guru-guru yang mengikuti sertifikasi, baik dalam menentukan kuota, menentukan orang, maupun kualifikasi akademik.

Hasil wawancara peneliti dengan sebagian guru-guru Sekolah Menengah Kejuruan Negeri di Malang Raya menunjukkan ada sebagian kepala sekolah yang belum menerapkan tugas dan fungsi pokok sebagai manajer, pengelola administrasi, supervisor, pemimpin (leader), pembaharu/inovator, pendorong (motivator). Dari pengamatan peneliti, peran kepala sekolah belum terlihat dalam menciptakan iklim yang kondusif, memecahkan konflik-konflik yang terjadi, atau memotivasi guru-guru untuk meningkatkan produktivitas kerjanya. Sebagian kepala sekolah lebih senang duduk di ruang dan tidak membantu para guru mengatasi permasalahanan pembelajaran peserta didik.

Di samping alasan-alasan tersebut, penelitian ini dilaksanakan pada Sekolah Menengah Kejuruan Negeri (SMK) Negeri di Malang Raya dengan pertimbangan sesuai dengan program Depdiknas bahwa hingga tahun 2015 direncanakan rasio siswa SMK dan SMA adalah $70 \%$ berbanding $30 \%$. Kebijakan ini diambil berdasarkan jumlah lulusan SMA yang bisa meneruskan ke perguruan tinggi hanya 30\%, sedangkan $70 \%$ tidak meneruskan ke perguruan tinggi dan harus bersaing dengan lulusan SMK untuk bersaing dalam dunia kerja. Dengan rasio jumlah siswa SMK yang lebih banyak diharapkan pengangguran terdidik dapat terkurangi, karena lulusan punya keterampilan yang memadai sesuai dengan kebutuhan dunia kerja. Di samping itu, peningkatan jumlah siswa SMK akan berdampak pada kebutuhan jumlah guru pada SMK lebih besar dibanding jumlah guru pada Sekolah Menengah Atas 
(SMA) (Dit. PSMK Depdiknas, 2009). Dengan adanya jumlah guru yang besar, problematika pendidikan di SMK juga akan meningkat dan memerlukan perhatian pemerhati pendidikan, masyarakat, dan pemerintah.

Secara khusus penelitian ini dilakukan pada SMK Negeri di Malang Raya dengan tujuan: (1) memperoleh gambaran persepsi tentang sertifikasi guru, strategi penyelesaian konflik, motivasi kerja guru, dan produktivitas kerja; (2) mengetahui ada tidaknya hubungan langsung yang signifikan antara: (a) persepsi tentang sertifikasi guru dengan motivasi kerja guru, (b) strategi penyelesaian konflik dengan motivasi kerja guru: (c) persepsi tentang sertifikasi guru dengan produktivitas kerja guru, (d) strategi penyelesaian konflik dengan produktivitas kerja guru; (e) motivasi dengan produktivitas kerja guru; (f) persepsi tentang sertifikasi guru dengan produktivitas kerja guru melalui motivasi kerja; (g) persepsi tentang sertifikasi guru, dan strategi penyelesaian konflik dengan motivasi kerja; dan (h) antara persepsi tentang sertifikasi guru, strategi penyelesaian konflik, dan motivasi kerja guru dengan produktivitas kerja.

\section{METODE}

Penelitian ini menggunakan rancangan penelitian deskripstif dan korelasionalyang merupakan bagian dari penelitian kuantitatif. Dalam penelitian ini, akan dicari hubungan antara: strategi penyelesaian konflik, persepsi tentang sertifikasi guru, dan motivasi kerja dengan produktivitas kerja guru di SMKN Malang Raya. Dari variabel-variabel yang diteliti dan berdasar variabel endegenous dan variabel exogeneous yang terkandung di dalamnya, model hubungan terbagi dalam dua bagian (blok). Bagian pertama yang merupakan variabel exogenousyaitustrategi penyelesaian konflik, dan persepsi tentang sertifikasi guru, dengan variabel endegenous adalah motivasi kerja. Bagian kedua merupakan variabel exogenous: strategi penyelesaian konflik, persepsi tentang sertifikasi guru, dan motivasi kerja guru dengan variabel endegenous produktivitas kerja.
Populasi dalam penelitian ini adalah guru-guru pada SMKN yang berstatus PNS di Malang Raya (Kota Malang, Kabupaten Malang, dan Kota Batu) yang mempunyai masa kerja lebih dari dua tahun, yang berjumlah 748 orang, dengan rincian jumlah guru Kota Malang 493 orang, Kabupaten Malang 244 orang, dan Kota Batu 93 orang. Berdasar formula Morgan dan Krejie (1970:607-610) jumlah sampel minimal untuk populasi 748 untuk signifikansi $5 \%$ adalah 238. Untuk mengantisipasi instrumen atau kuesioner yang tidak kembali atau jika kemungkinan terjadi beberapa kuesioner yang kembali tetapi tidak terisi secara lengkap, maka jumlah sampel perlu ditambah hingga menjadi 278 orang. Dari jumlah sampel tersebut yang kembali dan dapat dianalisis berjumlah 264 orang.

Instrumen dikembangkan dan dijabarkan dari variabel, sub-variabel dan indikator. Untuk variabel: (1) persepsi tentang sertifikasi guru terdiri dari 2 sub-variabel dan 7 indikator, (2) strategi penyelesaian konflik terdiri dari 14 sub-variabel dan 14 indikator, (3) variabel motivasi kerja terdiri dari 2 sub-variabel dan 10 indikator, dan (4) produktivitas kerja guru terdiri dari 6 sub-variabel dan 11 indikator.

Prosedur pengembangan instrumen melalui dua tahap, yaitu tahap penyusunan dan tahap uji coba. Tahap penyusunan dirancang dan dikonsultasikan (diuji) pada para ahli, yang kemudian diujicobakan untuk dilakukan uji validitas dan reliabilitasnya. Uji coba instrumen dilaksanakan menggunakan skala Likert untuk. Hasil uji validitas dari lima variabel yang tidak valid ada empat item (dibuang), dan hasil uji reliabilitas dinyatakan bahwa kelima variabel mempunyai validitas yang tinggi.

Data dianalisis dan deskriptifkanserta disajikan dalam bentuk: (1) tabel distribusi frekuensi, (2) menghitung rerata (mean) dan standar deviasi, (3) menggambarkan grafik, dan (4) mengkonversikan rerata ke dalam kriteria skala lima grafik dari masing-masing variabel. Teknik analisis data menggunakan Partial Least Square (PLS) yaitu suatu teknik analisis yang melakukan perbandingan antara variabel dependen berganda dan variabel independen 
berganda, yaitu dengan melakukan uji terhadap model pengukuran dan uji terhadap model structural (Sugiyono, 2008; Wibowo, 2004; Ghozali, 2008; dan Jogiyanto dan Abdilah, 2009). Untuk analisis PLS dilakukan Analisis Jalur (path analysis) yang meliputi: (1) pengujian terhadap Model Pengukuran dari setiap variabel, dan (2) pengujian terhadap Model Struktural

\section{HASIL DAN PEMBAHASAN}

Hasil analisis deskriptif untuk: (1) variabel persepsi tentang sertifikasi guru diperoleh mean 55,98 $(79,1 \%)$ termasuk dalam kategori tinggi, ini berarti Kebijakan tentang sertifikasi guru dan pelaksanaan sertifikasi guru dipersepsi secara positif karena guru telah diakui sebagai tenaga profesional dan kesejahteraannya meningkat; (2) variabel strategi penyelesaian konflik dengan mean sebesar 98,93 $(79,1 \%)$ termasuk dalam kategori tinggi, ini berarti bahwa sifat akomodatif, sifat kompromi, dan kolaboratif dari pimpinan dalam menyelesaikan konflik telah dilakukan oleh kepala sekolah; (3) variabel motivasi kerja diperoleh mean sebesar 90,47 $(75,67 \%)$ termasuk dalam kategori tinggi, ini berarti bahwa faktor ekstrinsik dan faktor intrinsik guru telah terpenuhi sehingga motivasi meningkat; dan (4) variabel produktivitas kerja guru diperoleh mean sebesar $79,23(66,46 \%)$ termasuk dalam kategori sedang, ini berarti bahwa guru-guru dalam merencanakan dan melaksanakan pembelajaran, melakukan penilaian dalam kategori cukup (belum maksimal). Secara khusus untuk indikator melakukan penelitian (PTK) dan menulis naskah/ artikel masih kategori rendah, serta indikator membuat media pembelajaran berada pada kategori sedang.

Hasil pengujian terhadap model pengukuran untuk konstruk persepsi tentang sertifikasi guru disajikan seperti Tabel 2 berikut.
Tabel 2. Hasil Uji Unidimensionalitas Konstruk Persepsi tentang Sertifikasi Guru

\begin{tabular}{lllll}
\hline \multicolumn{2}{c}{ Indikator Koefisien } & \multicolumn{1}{c}{$\mathrm{t}$} & \multicolumn{2}{c}{ Composite AVE } \\
& Korelasi & \multicolumn{1}{c}{ pengujian Reliabily } & \\
\hline $\mathrm{X}_{1}$ & 0,550 & 3,948 & & \\
$\mathrm{X}_{2}$ & 0,580 & 4,977 & & \\
$\mathrm{X}_{3}$ & 0,667 & 8,223 & & \\
$\mathrm{X}_{4}$ & 0,710 & 13,587 & 0,752 & 0,440 \\
$\mathrm{X}_{5}$ & 0,442 & 3,656 & & \\
$\mathrm{X}_{6}$ & 0,439 & 2,771 & & \\
$\mathrm{X}_{7}$ & 0,442 & 3,132 & & \\
\hline
\end{tabular}

Keterangan:

$\mathrm{X}_{1}=$ pemahaman tujuan sertifikasi guru sebagai upaya meningkatkan kualitas guru

$\mathrm{X}_{2}=$ pemahaman tujuan sertifikasi guru sebagai upaya meningkatkan kesejahteraan guru

$\mathrm{X}_{3}=$ pemahaman tujuan sertifikasi guru sebagai upaya pengakuan guru

$\mathrm{X}_{4}=$ persepsi tentang penyusunan portofolio;

$\mathrm{X}_{5}=$ persepsi tentang penilaian portofolio

$\mathrm{X}_{6}=$ persepsi tentang pelaksanaan PLPG

$\mathrm{X}_{7}=$ persepsi tentang kecukupan waktu pelaksanaan PLPG.

Hasil uji analisis didapat nilai t lebih besar dari t tabel $(1,96)$ pada taraf sisgnifikansi 0,05 , sehingga konstruk persepsi tentang sertifikasi guru menunjukkan hasil yang signifikan. Nilai faktor loading (korelasi antara skor item dengan skor konstruk)atau koefisien korelasi yang seluruhnya di atas 0,40, membuktikan setiap indikator memiliki tingkat validitas konstruk yang tinggi. Hasil pengujian diperoleh nilai composite reliability0,752 (lebih besar dari $0,70)$, yang berarti reliabilitas tinggi. Sedangkan nilai AVE (average variance extracted) sebesar 0,44 menunjukkan bahwa validitas diskriminan berada pada kategori cukup karena akar AVE lebih besar dari korelasi antara konstruk dengan konstruk lainnya dalam model.

Berdasar hasil analisis faktor konfirmatori, nilai loading paling tinggi terdapat pada indikator $\mathrm{X}_{4}$ yaitu persepsi tentang penyusunan portofolio $(0,71)$. Enam indikator lainnya yang mempunyai faktor loading lebih dari 0,40 dapat juga untuk menjelaskan bahwa persepsi tentang 
sertifikasi guru dapat dibentuk oleh $\mathrm{X}_{1}, \mathrm{X}_{2}, \mathrm{X}_{3}$, $\mathrm{X}_{5}, \mathrm{X}_{6}$, dan $\mathrm{X}_{7}$.

Hasil pengujian terhadap model pengukuran untuk konstruk Strategi Penyelesaian Konflik dapat dilihat pada Tabel 3 berikut.

Tabel 3. Hasil Uji Unidimensionalitas Konstruk Strategi Penyelesaian Konflik

\begin{tabular}{lllll}
\hline Indikator & $\begin{array}{l}\text { Koefisien } \\
\text { Korelasi }\end{array}$ & Rengujian & & \\
& Reliabilitas & AVE \\
\hline $\mathrm{X}_{8}$ & 0,454 & 4,452 & & \\
$\mathrm{X}_{9}$ & 0,571 & 5,853 & & \\
$\mathrm{X}_{10}$ & 0,778 & 18,683 & & \\
$\mathrm{X}_{11}$ & 0,716 & 12,094 & & \\
$\mathrm{X}_{12}$ & 0,450 & 4,026 & & 0,529 \\
$\mathrm{X}_{13}$ & 0,408 & 3,640 & & \\
$\mathrm{X}_{14}$ & 0,683 & 10,049 & 0,887 & \\
$\mathrm{X}_{15}$ & 0,717 & 12,653 & & \\
$\mathrm{X}_{16}$ & 0,477 & 4,937 & & \\
$\mathrm{X}_{17}$ & 0,788 & 17,660 & & \\
$\mathrm{X}_{18}$ & 0,808 & 22,805 & & \\
$\mathrm{X}_{19}$ & 0,563 & 6,662 & \\
$\mathrm{X}_{20}$ & 0,494 & 5,685 & \\
\hline
\end{tabular}

\section{Keterangan:}

$\mathrm{X}_{8}=$ Berorientasi pada kepentingan sendiri

$\mathrm{X}_{9}=$ Menggunakan sanksi-sanksi

$\mathrm{X}_{10}=$ Tidak terbuka

$\mathrm{X}_{11}=$ Bersikap tegas

$\mathrm{X}_{12}=$ Mengalah terhadap kemauan orang lain

$\mathrm{X}_{13}=$ Mementingkan kerja sama

$\mathrm{X}_{14}=$ Pengambilan

$\mathrm{X}_{15}=$ Bersikap kooperatif

$\mathrm{X}_{16}=$ Membujuk agar mau merelakan keinginannya

$\mathrm{X}_{17}=$ Berusaha berbuat adil

$\mathrm{X}_{18}=$ Pemenuhan kepentingan pihak yang berkonflik

$\mathrm{X}_{19}=$ Kerjasama

$\mathrm{X}_{20}=$ kesediaan untuk menerima pihak lain

Hasil uji analisis menghasilkan nilai t lebih besar dari t tabel $(1,96)$ pada taraf signifikansi 0,05 , sehingga konstruk strategi penyelesaian konflik menunjukkan hasil yang signifikan. Nilai faktor loading (koefisien korelasi) yang seluruhnya di atas 0,40 , membuktikan bahwa setiap indikator memiliki tingkat validitas terhadap konstruk yang tinggi. Hasil pengujian diperoleh nilai composite reliability sebesar 0,887 (lebih besar dari 0,70), yang berarti reliabilitasnya tinggi. Sedangkan nilai AVE sebesar 0,529 menunjukkan bahwa validitas diskriminan berada pada kategori cukup karena akar AVE lebih besar dari korelasi antara konstruk dengan konstruk lainnya dalam model.

Berdasar hasil analisis faktor konfirmatori nilai loading paling tinggi terdapat pada indikator $\mathrm{X}_{18}$ yaitu pemenuhan kepentingan pihak yang berkonflik $(0,81)$, yang merupakan pembentuk sub-variabel kolaboratif pimpinan. Dua belas indikator lainnya mempunyai faktor loading lebih dari 0,40 dapat juga untuk menjelaskan bahwa strategi penyelesaian konflik dapat dibentuk oleh $\mathrm{X}_{8}, \mathrm{X}_{9}, \mathrm{X}_{10}, \mathrm{X}_{11}$, $\mathrm{X}_{12}, \mathrm{X}_{13}, \mathrm{X}_{14}, \mathrm{X}_{15}, \mathrm{X}_{16}, \mathrm{X}_{17}, \mathrm{X}_{19}$, dan $\mathrm{X}_{20}$.

Hasil pengujian terhadap model pengukuran untuk konstruk Motivasi Kerja dapat dilihat pada Tabel 4 berikut.

Tabel 4. Hasil Uji Unidimensionalitas Konstruk Motivasi Kerja

\begin{tabular}{lllll}
\hline Indikator & Koefisien & $\mathrm{t}$ Uji & Reliabilitas & AVE \\
\hline $\mathrm{X}_{21}$ & 0,7167 & 13,686 & & \\
$\mathrm{X}_{22}$ & 0,4140 & 3,557 & & \\
$\mathrm{X}_{23}$ & 0,5986 & 6,686 & & \\
$\mathrm{X}_{24}$ & 0,7464 & 18,860 & & \\
$\mathrm{X}_{25}$ & 0,5571 & 6,185 & 0,888 & \\
$\mathrm{X}_{26}$ & 0,5268 & 5,946 & & \\
$\mathrm{X}_{27}$ & 0,7693 & 19,795 & & \\
$\mathrm{X}_{28}$ & 0,6587 & 10,415 & & \\
$\mathrm{X}_{29}$ & 0,7970 & 18,862 & & \\
$\mathrm{X}_{30}$ & 0,7174 & 13,622 & & \\
$\mathrm{X}_{31}$ & 0,5676 & 6,173 & & \\
\hline
\end{tabular}

Keterangan:

$\mathrm{X}_{21}=$ Kualitas pengawasan

$\mathrm{X}_{22}=$ Kecukupan gaji

$\mathrm{X}_{23}=$ Kebijakan sekolah

$\mathrm{X}_{24}=$ Hubungan antar pribadi

$\mathrm{X}_{25}=$ Suasana keamanan

$\mathrm{X}_{26}=$ Kondisi kerja

$\mathrm{X}_{27}=$ Peluang promosi

$\mathrm{X}_{28}=$ Peluang pertumbuhan personal

$\mathrm{X}_{29}=$ Pengakuan

$\mathrm{X}_{30}=$ Tanggung jawab

$\mathrm{X}_{31}=$ Prestasi

Hasil uji analisis didapat nilai t pengujian lebih besar dari t tabel $(1,96)$ pada taraf signifikansi 0,05 , sehingga konstruk motivasi kerja menunjukkan hasil yang signifikan. Nilai faktor loading (koefisien korelasi) seluruhnya bernilai 
di atas 0,40, membuktikan bahwa setiap indikator memiliki tingkat validitas terhadap konstruk yang tinggi. Hasil pengujian nilai composite reliability sebesar 0,888 (lebih besar dari 0,70 ), berarti konstruk motivasi kerja mempunyai reliabilitas tinggi. Sedangkan nilai AVE 0,526 menunjukkan bahwa validitas diskriminan berada pada kategori cukup karena akar AVE lebih besar dari korelasi antara konstruk dengan konstruk lainnya dalam model.

Berdasar hasil analisis faktor konfirmatori nilai loading paling tinggi pada indikator $\mathrm{X}_{29}$ yaitu pengakuan $(0,797)$. Dua belas indikator lainnya yang mempunyai faktor loading lebih dari 0,40 dapat juga untuk menjelaskan bahwa motivasi kerja dapat dibentuk oleh $\mathrm{X}_{21}$, $X_{22}, X_{23}, X_{24}, X_{25}, X_{26}, X_{27}, X_{28}, X_{30}$, dan $X_{31}$.

Hasil pengujian terhadap model pengukuran untuk konstruk Produktivitas Kerja dapat dilihat pada Tabel 5 berikut.

\section{Tabel 5. Hasil Uji Unidimensionalitas Kons-} truk Produktivitas Kerja Guru

\begin{tabular}{lllll}
\hline Indikator & $\begin{array}{l}\text { Koefisien } \\
\text { Korelasi }\end{array}$ & $\mathrm{t}$ & Reliabilitas & AVE \\
\hline $\mathrm{Y}_{1}$ & 0,5249 & 4,330 & & \\
$\mathrm{Y}_{2}$ & 0,7483 & 14,349 & & \\
$\mathrm{Y}_{3}$ & 0,7223 & 12,169 & & \\
$\mathrm{Y}_{4}$ & 0,4739 & 4,033 & & \\
$\mathrm{Y}_{5}$ & 0,4648 & 3,888 & 0,8532 & 0,556 \\
$\mathrm{Y}_{6}$ & 0,4380 & 3,537 & & \\
$\mathrm{Y}_{7}$ & 0,4562 & 3,481 & & \\
$\mathrm{Y}_{8}$ & 0,4811 & 4,501 & & \\
$\mathrm{Y}_{9}$ & 0,7346 & 14,830 & & \\
$\mathrm{Y}_{10}$ & 0,7033 & 9,646 & & \\
$\mathrm{Y}_{11}$ & 0,6705 & 10,901 & & \\
\hline
\end{tabular}

\section{Keterangan:}

$\mathrm{Y}_{1}=$ perencanaan pembelajaran,

$\mathrm{Y}_{2}=$ Pelaksanaan pembelajaran,

$\mathrm{Y}_{3}=$ Pembimbingan siswa,

$\mathrm{Y}_{4}=$ Pembimbingan PPL dan teman sejawat,

$\mathrm{Y}_{5}=$ Penelitian tindakan kelas (PTK),

$\mathrm{Y}_{6}=$ Penulisan artikel,

$\mathrm{Y}_{7}=$ Media pembelajaran,

$\mathrm{Y}_{8}=$ Penggunaan media pembelajaran,
Y9 = Tingkat pencapaian kelulusan,

$\mathrm{Y}_{10}=$ Tingkat pencapaian kenaikan,

$\mathrm{Y}_{11}=$ Pelatihan yang dikuti

Hasil uji analisis diperoleh nilai t pengujian lebih besar dari t tabel $(1,96)$ pada taraf sisgnifikansi 0,05 , sehingga konstruk produktivitas kerja guru menunjukkan hasil yang signifikan. Nilai faktor loading (koefisien korelasi) yang seluruhnya bernilai di atas 0,40 , memberikan bukti bahwa setiap indikator memiliki tingkat validitas terhadap konstruk yang tinggi. Hasil pengujian diperoleh nilai composite reliability sebesar 0,853 (lebih besar dari 0,70), yang berarti konstruk produktivitas kerja guru mempunyai reliabilitas tinggi. Sedangkan nilai AVE 0,556 menunjukkan bahwa validitas diskriminan berada pada kategori cukup karena akar AVE lebih besar dari korelasi antara konstruk dengan konstruk lainnya dalam model.

Berdasar hasil analisis faktor konfirmatori nilai loading paling tinggi terdapat pada indikator $\mathrm{Y}_{2}$ yaitu pelaksanaan pembelajaran $(0,748)$. Sepuluh indikator lainnya yang mempunyai faktor loading lebih dari 0,40 dapat juga untuk menjelaskan bahwa produktivitas kerja guru dapat dibentuk oleh Y1, Y3, Y4, Y5, Y6, Y7, Y8, Y9, Y10, dan Y11.

Pengujian terhadap model struktural yang merupakan uji signifikan pengaruh antar jalur berdasar hasil kalkulasi (calculate) model struktural dan bootstrapping dengan menggunakan program software SmartPLS 2 dilakukan dua kali. Hasil analisis model struktural awal menunjukkan bahwa ada satu hubungan yang tidak signifikan, yaitu antara variabel persepsi tentang sertifikasi guru dengan produktivitas kerja guru (nilai koefisien $-0,0185$, dengan $\mathrm{t}=$ 0,2881 ). Dengan demikian perlu ada perbaikan model, dengan menghapus hubungan yang tidak signifikan.Hasil analisis dengan model evalusi diperoleh Tabel 6 dan gambar model struktural berikut. 
Tabel 6 Hasil Uji Hipotesis Model Struktural (Evaluasi)

\begin{tabular}{lclcc}
\hline Arah Jalur & & & Koefisien & $\mathrm{t}$ \\
\hline Strategi Penyelesaian Konflik (SPK) & $\rightarrow$ & Prodruktivitas Kerja (PK) & 0,2628 & 2,307 \\
Motivasi Kerja (MK) & $\rightarrow \quad$ Prodruktivitas Kerja (PK) & 0,3565 & 2,383 \\
Persepsi ttg Sertifikasi Guru (PSG) & $\rightarrow$ Motivasi Kerja (MK) & 0,2429 & 3,886 \\
Strategi Penyelesaian Konflik (SPK) & $\rightarrow$ Motivasi Kerja (MK) & 0,3697 & 3,041 \\
\hline
\end{tabular}

Sumber: Data primer yang diolah (2010)

R-square $\mathrm{MK}=0,636 ; \quad$ R-square $\mathrm{PK}=0,768$

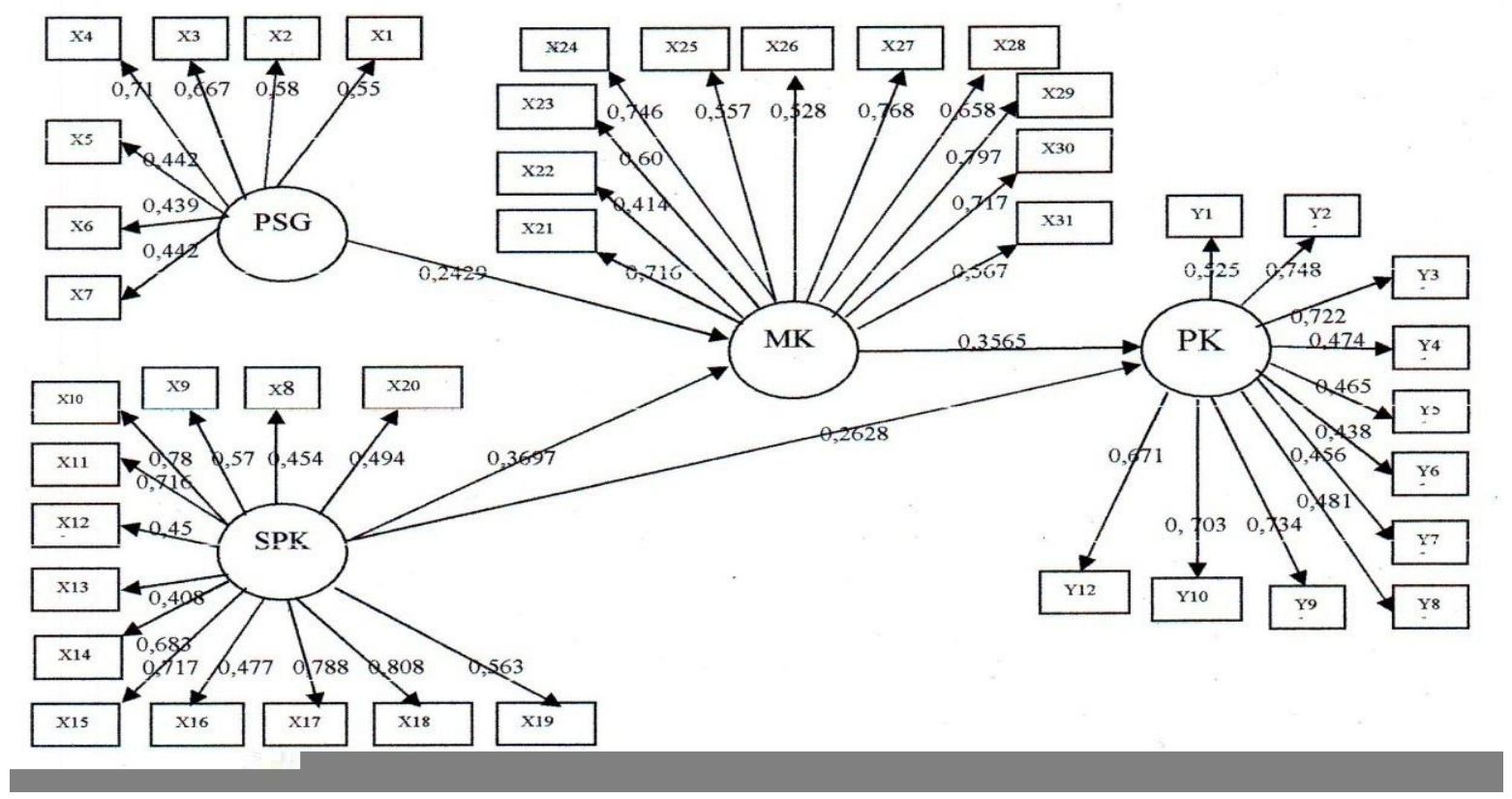

\section{Gambar 1: Hasil Model Struktural Evaluasi Variabel Persepsi tentang Sertifikasi Guru, Strategi Penyelesaian Konflik, Motivasi Kerja, dan Produktivitas Kerja}

Berdasar hasil analisis yang ditunjukkan pada tabel 7 dan gambar 1 menunjukkan bahwa hubungan antara semua variabel bebas (exogen) dengan variabel terikat (endogen), baik antara: (1) persepsi tentang sertifikasi guru, strategi penyelesaian konflik dengan motivasi kerja, dan (2) persepsi tentang sertifikasi guru, strategi penyelesaian konflik, motivasi kerja dengan produktivitas kerja; semua mempunyai nilai pengujian di atas 1, 96 (untuk signifikansi 0,05). Dengan demikian dapat diisimpulkan: (1) ada pengaruh langsung yang signifikan antara persepsi tentang sertifikasi guru dengan motivasi kerja dengan nilai $\mathrm{r}=0,243$; (2) ada pengaruh langsung yang signifikan antara strategi penyelesaian konflik dengan motivasi kerja guru dengan nilai $r=0,370$; (3) ada pengaruh langsung yang signifikan antara strategi penye- lesaian konflik dengan produktivitas kerja dengan nilai $r=0,263$; (4) ada pengaruh langsung yang signifikan antara motivasi kerja dengan produktivitas kerja guru dengan nilai $r=0,357$.

Hasil analisis data menunjukkan bahwa ada pengaruh antara persepsi tentang sertifikasi dengan motivasi kerja guru. Hasil ini menunjukkan adanya hubungan antara persepsi tentang sertifikasi dengan motivasi kerja ini sesuai dengan teori Maslow (dalam Daft, 2003: 173) yang menyatakan: (1) penghargaan ekonomi diberikan pada karyawan atas kerja tinggi, penekanan pada gaji berkembang menjadi pemikiran manusia ekonomi, dimana orang akan bekerja keras (termotivasi) demi gaji yang lebih tinggi (hal ini berarti bahwa motivasi guru meningkat dengan mendapatkan penghasilan yang tinggi melalui sertifikasi); dan (2) kebutuhan akan 
penghargaan (esteem needs) merupakan kebutuhan-kebutuhan yang berkenaan dengan keinginan akan kesan diri yang positif dan untuk menerima perhatian, pengakuan, dan apresiasi dari orang lain.

Dalam organisasi, kebutuhan akan penghargaan mencerminkan motivasi untuk mendapatkan pengakuan, peningkatan tanggung jawab, status tinggi, dan pujian atas kontribusi bagi organisasi (hal ini berarti motivasi guru meningkat dengan mendapatkan pengakuan dan penghargaan berupa sertifikat pendidik melalui sertifikasi). Dari pernyataan tersebut, disimpulkan bahwa pendapatan (gaji) yang tinggi, pengakuan, dan penghargaan dapat meningkatkan motivasi, dan ini sejalan dengan tujuan sertifikasi guru, yang diantaranya untuk meningkatkan kesejahteraan guru dan meningkatkan keprofesionalitas guru (Depdiknas, 2009).

Hasil analisis data menunjukkan bahwa ada pengaruh yang signifikan antara strategi penyelesaian konflik dengan motivasi kerja. Hasil analisis ini sesuai dengan teori Wexley dan Yukl (1992) mengemukakan enam kategori penting sebagai kondisi yang menimbulkan konflik, yaitu: (1) persaingan terhadap sumbersumber, (2) ketergantungan pekerjaan, (3) kekaburan bidang tugas, (4) problem status, (5) rintangan komunikasi, dan (6) perbedaan sifatsifat individu. Robbins (2003: 202) menyampaikan metode pengurangan konflik dengan jalan mensubtitusi tujuan-tujuan yang dapat diterima oleh kelompok-kelompok yang sedang konflik, menghadapkan tantangan baru kepada kedua belah pihak agar dihadapi secara bersama sehingga motivasi meningkat.

Hasil analisis data menunjukkan bahwa tidak ada pengaruh antara persepsi tentang sertifikasi guru dengan produktivitas kerja.Hasil penelitian ini sesuai dengan yang dikatakan Baedhowi dalam pidato pengukuhan guru besarnya yang dikutip oleh Untari (2008), menyatakan bahwa persepsi yang ditangkap guru tentang sertifikasi hanya sebatas peningkatan kesejahteraan. Dari hasil penelitiannya yang melibatkan responden yang berjumlah 3670, hanya $0,9 \%$ yang menyatakanterjadi peningkatan kompetensi pedagogik guru yang lulus sertifikasi melalui penilaian portopolio dan PLPG, $54 \%$ menyatakan tidak meningkat, bahkan $44 \%$ malah terjadi penurunan kinerja.

Hasil analisis data menunjukkan bahwa ada pengaruh yang signifikan antara strategi penyelesaian konflik dengan produktivitas kerja. Temuan penelitian ini sejalan dengan teori Maidique \& Hayes (1989:27) yang mengatakan bahwa kejujuran, ketulusan, keterbukaan, keutuhan, dan tidak adanya konflik berpengaruh pada peningkatan produktivitas kerja. Fox (1989:40) menjelaskan bahwa produktivitas kerja dipengaruhi oleh pemecahan masalah bersama dalam rangka mengurangi konflik yang terjadi. Lebih lanjut Lorange \& Nelson (1989:65) menjelaskan terjadinya konflik antar individu atau kelompok yang tidak terpecahkan dapat menurunkan produktivitas kerja. Pendapat Suwardani (1997) memperkuat pendapatpendapat di atas, yang mengatakan konflik dalam organisasi apabila dimanfaatkan dan ditangani secara baik dapat meningkatkan produktivitas organisasi. Ranftl (1989:108) menjelaskan bahwa stimulasi (yang merupakan variabel manajemen konflik), keterbukaan, dan suasana yang kreatif dimana orang dapat menjadi dirinya sendiri dapat mendorong motivasi dan produktivitas kerja.

Hasil analisis data menunjukkan bahwa ada pengaruh yang signifikan antara motivasi kerja dengan produktivitas kerja.Temuan penelitian ini sejalan dengan Ranftl (1989:111) yang mengatakan motivasi disebut sebagai faktor kritis dan pegawai yang termotivasi berada di jalan produktivitas tinggi. Pengamatan yang khas: dapat memotivasi diri sendiri, penuh inisiatif, tekun, mempunyai kemamuan yang keras, menyukai tantangan, selalu ingin bertanya, memperagakan ketidakpuasan yang konstruktif, berorientasi pada hasil, selalu tepat waktu dan ingin menepati waktu, percaya bahwa kerja wajar sehari perlu diimbangi dengan gaji wajar untuk sehari, merasa puas jika sudah, dan mengerjakan tugas dengan baik, dan memberikan andil lebih dari yang diharapkan. Daft (2003: 120) menjelaskan sebagian besar organisasi mengembangkan rencana-rencana kompensasi berdasarkan standar pembayaran pada kinerja 
untuk meningkatkan produktivitas dan memotong biaya lain dalam lingkungan persaingan global. Kompensasi dalam hal ini meliputi upah/gaji, asuransi kesehatan, liburan yang dibayar oleh organisasi. Lebih lanjut Daft menambahkan motivasi seseorang mempengaruhi produktivitas, dan sebagian tugas seorang manajer adalah menyalurkan motivasi menuju pencapaian tujuan-tujuan organisasional.

\section{PENUTUP}

Berdasar hasil analisis deskriptif dan pembahasan dari kelima variabel yang diteliti disimpulkan sebagai berikut: (1) persepsi tentang sertifikasi guru SMKN di Malang Raya berada pada kategori tinggi, (2) strategi penyelesaian konflik SMKN di Malang Raya berada pada kategori tinggi, (3) motivasi kerja guru SMKN di Malang Raya berada pada kategori tinggi; dan (4) produktivitas kerja guru SMKN di Malang Raya berada pada kategori sedang, dengan frekuensi melakukan penelitian tindakan kelas dan frekuensi menulis artikel rendah.

Berdasar hasil uji hipotesis dan pembahasan disimpulkan: (1) ada hubungan langsung yang signifikan antara persepsi tentang sertifikasi guru dengan motivasi kerja; (2) ada hubungan langsung yang signifikan antara strategi penyelesaian konflik dengan motivasi kerja; (3) tidak ada hubungan langsung yang signifikan antara persepsi tentang sertifikasi guru dengan produktivitas kerja; (4) ada hubungan langsung yang signifikan antara strategi penyelesaian konflik dengan produktivitas kerja; (5) ada hubungan langsung yang signifikan antara motivasi kerja dengan produktivitas kerja.

\section{UCAPAN TERIMA KASIH}

Penulis mengucapkan terima kasih kepada subjek penelitian guru-guru pada SMKN yang berstatus PNS di Malang Raya (Kota Malang, Kabupaten Malang, dan Kota Batu), mitra bestari yang telah berkenan membaca, mengoreksi, secara cermat dan memberikan saran perbaikan, teman sejawat sebagai mitra diskusi demi kualitas penelitian ini, dan redaktur yang telah memberikan saran dan kritik demi perbaikan tulisan ini.

\section{DAFTAR PUSTAKA}

Brookfiled, K.L. (Ed.). Dimensi-dimensi Peningkatan Produktivitas. Alih bahasa Soesanto Boedidarmo.Jakarta: PT Elex Media Indonesia.

Departemen Pendidikan Nasional. 2009. Pedoman Penetapan Peserta dan Pelaksanaan Sertifikasi Guru dalam Jabatan. Jakarta: Direktorat Jenderal Peningkatan Mutu Pendidik dan Tenaga Kependidikan Departemen Pendidikan Nasional

Daft, R.L. 2003. Management. Alih Bahasa Diana Angelica 2006. Jakarta: Salemba Empat.

Ghozali, I. 2008. Struktural Equation Modeling, Metode Alternatif dengan Partial Least Square PLS. Semarang: Badan Penerbitan Universitas Diponegoro.

Fox, H.W. (ed.). 1989. Mengeluarkan Produktivitas yang Tersembunyi. Alih bahasa Soesanto Boedidarmo. Jakarta: PT Elex Media Indonesia.

Hersey, P. \& Blanchard, K. 1986.Management of Organizational Behavior: Utilizing Human Resources (4 $4^{\text {th }}$ edition). EnglewoodCliffs, N.J.: Prentice-Hall, Inc. Jogiyanto dan Abdilah, W. 2009. Konsep dan Aplikasi PLS untuk Penelitian Empiris. Yogyakarta: BPFE-Yogyakarta.

Kreps, G.L. (1986). Organizational Communication Theory. New York: Longman.

Lorange, P. \& Nelson, R.T. (ed.). 1989. Bagaimana Menerima dan Menghindari Kemerosotan Organisasi. Alih bahasa Soesanto Boedidarmo. Jakarta: PT Elex Media Indonesia.

Maidique, M.A. \& Hayes, R.H. (Ed.). 1989. Seni dari Manajemen Teknologi Tinggi. Alih bahasa Soesanto Boedidarmo. Jakarta: PT Elex Media Indonesia. 
Morgan, D.W. and Krejcie, R.V. 1970. Ditermining Sample Size for Research Activities, "Educational and Osychological Measurement “, Vol.30, p.607-610.

Ranftl, M.R. (ed.). 1989. Tujuh Kunci untuk Produktivitas Tinggi. Alih bahasa Soesanto Boedidarmo. Jakarta: PT Elex Media Indonesia.

Robbins, S.P. 2003. Organizational Behavior. Alih Bahasa Benyamin Molan, 2006. New Jersey: Prentice-Hall, Inc.

Schippers, U. \& Patriana, D.M. 1993. Pendidikan Kejuruan Indonesia. Bandung: PT. Angkasa

Salabi, A. 2006. Hubungan Keterampilan Manajerial Kepala Sekolah, Komunikasi Organisasi, pengendalian Konflik, dan Iklim Organisasi dengan Keefektifan Organisasi Madrasah Aliyah Negeri di Propinsi Kalimantan selatan. Desertasi tidak diterbitkan. Malang: PPS Universitas Negeri Malang.

Sudarman. 2008. Persepsi Guru terhadap Program Sertifikasi. (online), (http://www. Scribd.com/doc/. Diakses 27 Januari 2010).

Sugiyono. 2008. Statistika untuk Penelitian. Bandung: Penerbit Alfabeta.

Supriyanto. 2005. Pengaruh Motivasi terhadap Kinerja Guru SMA di Bandung (online), (http://www. tesis-ilmiah.co.cc. Diakses tanggal 3 Nopember 2008)
Suparlan. 2009. Penilaian Portofolio: Sertifikasi Guru dalam Jabatan. (Online), (http://www.suparlan.com/pages/posts/. Diakses 15 Pebruari 2010).

Suparlan. 2005. Menjadi Guru efektif. Yogyakarta: Hikayat Publishing.

Suwardani, N.P. 1997. 'Penggunaan Teknik Pengendalian Konflik Organisasi oleh Kepala Sekolah dalam Hubungannya dengan Performansi Kerja Guru SLTPN se Kodya Denpasar". Tesis Tidak Diterbitkan. Malang: Program Pascasarjana IKIP Malang

Untari, Atiek. 2008. Sertifikasi Guru Belum Jamin Peningkatan Mutu Guru. (online), (http://www.dradio1034fm.or.id/. Diakses 3 Pebruari 2010)

Wexley, K.N. \& Yukl, G.A. 1992. Perilaku Organisasi dan Psikologi Personalia. Alih bahasa Muh. Shobaruddin. Jakarta Rineka Cipta.

Wibowo, A. 2004.Pengantar Structural Equation Modeling. Malakah disajikan dalam Pelatihan SEM, Lembaga Penelitian Universitas Erlangga Surabaya, Surabaya, 15-18 Juni 2004. 